\title{
Empirical Study of the Dividend Policy of Russian Companies at the Present Stage
}

\author{
Irina Alekseevna Filippova ${ }^{1}$, Milyausha Kharisovna Biktemirova ${ }^{2}$, Evgeniya Yurievna Strelnik ${ }^{1} \&$ Rustam Rinatovich \\ Salikhov ${ }^{1}$ \\ ${ }^{1}$ Department of Corporate Finance, Institute of Management, Economics and Finance, Kazan Federal University \\ (IMEF KFU), Russia \\ ${ }^{2}$ Department of Production Economics, Institute of Management, Economics and Finance, Kazan Federal University \\ (IMEF KFU), Russia \\ Correspondence: Irina Alekseevna Filippova, $\mathrm{PhD}$ in Economics, Assistant Professor at the Department of Corporate \\ Finance, Institute of Management, Economics and Finance, Kazan Federal University (IMEF KFU), Russia. E-mail: \\ Filippova_Irina_aleks@mail.ru
}

Received: October 9, 2020

doi:10.5430/ijfr.v12n2p369
Accepted: December 5, 2020

Online Published: January 19, 2021

URL: https://doi.org/10.5430/ijfr.v12n2p369

\begin{abstract}
Many of the theoretical issues related to the company's dividend policy are highly debatable and sometimes controversial. This article presents the results of an empirical analysis of dividend payments of 50 large Russian public companies for the period from 2011 to 2018. The main source of information in the formation of the empirical base was the data of the annual accounting statements of public companies. During the study, hypotheses about the interrelations of dividend payments and market capitalization, as well as performance indicators and indicators that characterize financial and investment policies had been tested. According to the results, a number of analyzed factors, including revenue, the presence of the state and foreign investors in the ownership structure, financial leverage ratio, the absorption factor per cent, and return on invested capital turned out to be statistically insignificant. Among factors that have a statistically significant association with the dividend payments are market capitalization, net profit, return on assets, return on equity, average total assets. In the course of substantiating and making dividend payout decisions, company management should evaluate, predict and take into account the intricacies of dividend payments with financial and investment decisions. At the same time, the main task of management is to find the optimal amount of dividend payments and thus to meet the expectations of shareholders.
\end{abstract}

Keywords: dividend policy, Russian public companies, empirical analysis, factor models, multiple regression models

\section{Introduction}

The dividend policy of domestic public companies is an important component of the financial strategy. Until the beginning of the last decade, the absence of any kind of dividend policy was a typical phenomenon in the practice of Russian companies. In modern realities, many domestic companies began to introduce provisions on dividend policy, but so far it is premature to talk about the formation of the principles of dividend policy formation and optimization.

Since the mid-1950s, John Lintner have been carrying out the in-depth studies on determining the amount of dividend payments. According to the Lintner model, the number of dividends depends on current income, profit and dividends paid in the previous year, the value of the normative coefficient of dividend payments (Litner, 1956; Fama \& Babiak, 1968).

E. Fama and C. French analyzed the data of American companies in the formation terms of dividend policy for the period from 1926 to 1999 and concluded that among the determining factors were the size of the company, its investment opportunities and profitability (Fama \& French, 2001).

Besides the above-mentioned factors, managers of large foreign companies also take into account such factors as: preferences of shareholders, liquidity of the company, statutory restrictions, restrictions in loan agreements, inflation rate (Baker \& Powell, 1999; Dhanani, 2005).

Domestic scholars also highlight a number of factors that have a significant impact on the dividend payment policy of Russian public companies, among which are tax and dividend payment legislation, stability of the financial condition 
of companies, the need for additional financing, dividend preferences of majority shareholders and a number of others (Леванова, 2019; Козлова, 2015; Теплова \& Зальцман, 2015).

One of the urgent tasks today is to conduct further empirical studies on the dividend policy of Russian public companies in order to identify the main characteristics, trends and factors that have a significant impact on policy formation.

\section{Methodology}

The study of the characteristics and development trends of dividend policy in Russian companies is an important stage for understanding its significance and trying to apply formalized approaches to its formation.

For the purposes of studying the dividend payment policy, the time period from 2011 to 2018 is chosen and included in the empirical base 50 large public domestic companies in seven different sectors of the economy, including oil and gas, metallurgy and mining, electricity, chemistry and petrochemistry, telecommunications, transport and other sectors. The main source of information used was the data of the companies' annual financial statements published in the SPARK-Interfax database (https://spark-interfax.ru).

The study of the dividend policy of public companies from the empirical base began with an assessment of the size and proportion of dividends paid on net profit and revenue.

Table 1 demonstrates the calculated averaged percentage value of net profit allocated by companies for the payment of dividends in each sector.

Table 1. Average value percentage of dividend payment from net profit

\begin{tabular}{ccccccccc}
\hline \multirow{2}{*}{ Sector } & \multicolumn{7}{c}{ Year } \\
\cline { 2 - 8 } & 2011 & 2012 & 2013 & 2014 & 2015 & 2016 & 2017 & 2018 \\
\hline Metallurgy and mining & $14 \%$ & $17 \%$ & $16 \%$ & $40 \%$ & $54 \%$ & $45 \%$ & $40 \%$ & $46 \%$ \\
\hline Oil and gas & $50 \%$ & $54 \%$ & $65 \%$ & $79 \%$ & $>100 \%$ & $71 \%$ & $75 \%$ & $63 \%$ \\
\hline Telecommunication & $30 \%$ & $22 \%$ & $34 \%$ & $22 \%$ & $53 \%$ & $38 \%$ & $33 \%$ & $38 \%$ \\
\hline Transport & $1 \%$ & $2 \%$ & $2 \%$ & $5 \%$ & - & $23 \%$ & $7 \%$ & - \\
\hline $\begin{array}{c}\text { Chemistry and } \\
\text { petrochemistry }\end{array}$ & $10 \%$ & $9 \%$ & $4 \%$ & $27 \%$ & $44 \%$ & $8 \%$ & $4 \%$ & - \\
\hline Electric power & $1 \%$ & $6 \%$ & $8 \%$ & $10 \%$ & $39 \%$ & $10 \%$ & $6 \%$ & $3 \%$ \\
\hline Others & $3 \%$ & $4 \%$ & $6 \%$ & $35 \%$ & $26 \%$ & $7 \%$ & $7 \%$ & $2 \%$ \\
\hline
\end{tabular}

In order to define more accurately the dividend policy type of selected companies, calculations of the dividend payments share from revenue had been undertaken. Table 2 shows the averaged value percentage of dividend payments from revenue in each sector.

Table 2. The average value percentage of revenue aimed at paying dividends

\begin{tabular}{ccccccccc}
\hline \multirow{2}{*}{ Economic sector } & \multicolumn{7}{c}{ Year } \\
\cline { 2 - 9 } & 2011 & 2012 & 2013 & 2014 & 2015 & 2016 & 2017 & 2018 \\
\hline Metallurgy and mining & $5 \%$ & $5 \%$ & $6 \%$ & $17 \%$ & $12 \%$ & $18 \%$ & $17 \%$ & $17 \%$ \\
\hline Oil and gas & $26 \%$ & $20 \%$ & $28 \%$ & $26 \%$ & $31 \%$ & $30 \%$ & $37 \%$ & $18 \%$ \\
\hline Telecommunication & $7 \%$ & $3 \%$ & $9 \%$ & $3 \%$ & $4 \%$ & $6 \%$ & $7 \%$ & $2 \%$ \\
\hline Transport & $0,1 \%$ & $0,2 \%$ & $0,3 \%$ & $0,3 \%$ & - & $2,5 \%$ & $0,9 \%$ & - \\
\hline $\begin{array}{c}\text { Chemistry and } \\
\text { petrochemistry }\end{array}$ & $1,8 \%$ & $1,2 \%$ & $0,7 \%$ & $1,8 \%$ & $1,8 \%$ & $1,2 \%$ & $0,5 \%$ & - \\
\hline Electric power & $0,5 \%$ & $1,6 \%$ & $2,7 \%$ & $1,6 \%$ & $2,8 \%$ & $3,1 \%$ & $2,5 \%$ & $0,1 \%$ \\
\hline Others & $0,2 \%$ & 0,7 & $1,1 \%$ & $2,5 \%$ & $1,9 \%$ & $1,1 \%$ & $1,5 \%$ & $0,1 \%$ \\
\hline
\end{tabular}


While analyzing the data on the share of dividends in the revenue and net profit of the selected companies, it is relevant to assume the particular type of dividend policy in the sector. Thus, oil and gas companies adhere to an aggressive dividend policy, as $70 \%$ of net income and $27 \%$ of revenue are spent on dividend payments to shareholders. Moreover, companies in this sector not once have made dividend payments in excess of net profit. Mining and telecom companies take a moderate approach in paying dividends. These companies spend $34 \%$ and $27 \%$ of net profit in the form of dividends, respectively; whereas the value of dividends in these sectors accounts for $5 \%$ of revenue. Companies in the above-mentioned sectors do not distribute the same amount of money on the dividend payments each year; the share of dividends from net income ranges from $14 \%$ to $54 \%$. The dividend policy of mining and telecommunication companies should rather be described as a compromise. In other sectors, the share of dividends from the net profit is insignificant and ranges from $5 \%$ to $10 \%$, that makes it possible to characterize such type of dividend policy as conservative.

At the next stage of this study, the following four hypotheses were formulated and tested:

- The dividend policy of domestic public companies has an impact on market capitalization;

- Performance indicators of domestic companies have a significant interrelation with the size of dividend payments;

- Indicators characterizing the financial policy regarding the choice of financing sources, and the dividend payout policy are interconnected;

- Indicators reflecting the company's investment policy have a significant connection with the dividend policy.

Statistical testing of these hypotheses was carried out in the Ms Excel application with the use of the Data Analysis add-on and application of the methods and models of multifactor correlation-regression. The general form of the linear multiple regression model is reflected by the following formula:

$$
\mathrm{Y}=\mathrm{a}+\mathrm{b}_{1} * \mathrm{x}_{1}+\mathrm{b}_{2} * \mathrm{x}_{2}+\mathrm{b}_{3} * \mathrm{x}_{3}+\mathrm{b}_{4} * \mathrm{x}_{4}+\mathrm{b}_{5} * \mathrm{x}_{5}+\mathrm{b}_{6} * \mathrm{x}_{6},
$$

Where $\mathrm{Y}$ is the number of dividends paid on common shares;

$\mathrm{b}_{1}, \mathrm{~b}_{2}, \mathrm{~b}_{3} \ldots \mathrm{b}_{\mathrm{n}}$ - Regression equation coefficients;

$\mathrm{X}_{1}, \mathrm{X}_{2}, \mathrm{X}_{3} \ldots \mathrm{X}_{\mathrm{n}}$ - Selected factor variables (independent regressors).

Since both absolute and relative indicators were chosen for the purpose of statistical research, the natural logarithms of absolute values were used for comparability of the analyzed data.

In order to test the first two hypotheses regarding the impact of dividend policy on the market capitalization of companies and the connection between dividend payments and the company's performance indicators, these are chosen at the first stage as the resulting factor $(\mathrm{Y})$ - the amount of dividends paid on common shares and as independent regressors - net profit (X1); the presence of the state among the owners (X2); belonging to the oil and gas sector (X3); capitalization (X4); revenue (X5); the presence of foreign investors (X6).

Hypotheses testing was carried out in several stages. After constructing the correlation matrix and excluding insignificant factors, It is obtained a regression model of the following form:

$$
Y=-34,913+0,284 * X_{1}+1,820 * X_{2}+1,679 * X_{3}
$$

Table 3. Regression statistics

\begin{tabular}{cc}
\hline Indicator & Value \\
\hline Multiple $\mathrm{R}^{2}$ & 0,688508265 \\
\hline $\mathrm{R}^{2}$ & 0,474043631 \\
\hline Normalized $\mathrm{R}^{2}$ & 0,464651553 \\
\hline Standard error & 7,878466347 \\
\hline Monitoring (quantity) & 400 \\
\hline
\end{tabular}

The fact that the value of the coefficient of multiple correlation amounts to 0.689 indicates a significant interrelation between the number of dividends paid on common shares with such independent regressors as net profit, belonging to the oil and gas sector, and capitalization. The coefficient value of determination is 0.474 , that means that the variation 
in the resultant variable is attributable for $47.4 \%$ to the variation in the explanatory variables of the model.

The hypothesis about the statistical significance of the regression equation was tested by comparing the actual and critical (tabular) values of the F-Fisher' criterion. This model is statistically significant at a significance level of 95\%, since the following inequality is applied: $(\mathrm{F}$ critical $=2.395)<(\mathrm{F}$ observed $=76.012)$.

The significance of the regression coefficients was also observed using Student's t-test. From Table 4, it seems that that all three selected regressors of this model are considered significant, since all observed values of the modulo t-statistics are greater than the critical value.

Table 4. Comparison of observed values of students' t-test with critical values of t-statistics

\begin{tabular}{ccc}
\hline Indicator & $\mathrm{t}_{\text {наблюдаемое }}$ & $\mathrm{t}_{\text {критическое }}$ \\
\hline Y-intersection & $-6,998524944$ & 2,249 \\
\hline Net profit & 5,841329644 & 2,249 \\
\hline Belonging to oil and gas sectors & 5,128200019 & 2,249 \\
\hline Capitalization & 8,123438384 & 2,249 \\
\hline
\end{tabular}

The Goldfeld-Quandt test for heteroscedasticity was applied in order to verify the fulfillment of the prerequisites when using the least squares method. The presence of heteroscedasticity indicates the inhomogeneity of observations, that is expressed in the volatility of the random error of the regression model. Heteroscedasticity was not detected in the model; therefore, the residues are homoscedastic at the $95 \%$ probability level. This test reflects the homogeneity of the sample for each of the three-independent model regressors.

All the previous stages of the performed regression analysis confirm the hypothesis that there is a connection between the dividend policy and the company's capitalization and performance indicators.

At the next stage of the statistical analysis, the following two hypotheses were tested by defining a connection between decisions on dividend payments and the financial and investment policies of the company. The value of dividends paid on common shares was taken as the resulting factor $(\mathrm{Y})$, and the following factors were selected as independent regressors: financial leverage ratio (X1); return on assets (X2); interest coverage ratio (X3); average annual value of assets (X4); return on invested capital (X5); return on equity (X6).

As a result of constructing a pair correlation matrix and checking factors for multicollinearity and significance, only three out of six factors were included in the regression model. The resulting equation of multivariate linear regression is reflected in the following formula:

$$
Y=8,508+19,701 * X_{1}+0,181 * X_{2}+1,241 * X_{3}
$$

The results of constructing the regression equation are shown in Table 5.

Table 5. Regression statistics

\begin{tabular}{cc}
\hline Indicator & Value \\
\hline Multiple $\mathrm{R}^{2}$ & 0,61653968 \\
\hline $\mathrm{R}^{2}$ & 0,408428479 \\
\hline Normalized $\mathrm{R}^{2}$ & 0,402431725 \\
\hline Standard error & 9,616285441 \\
\hline Monitoring (quantity) & 400 \\
\hline
\end{tabular}

The value of the multiple correlation coefficient in this model is 0.617 , as can be observed from Table 5. This fact indicates a significant connection between the number of dividends paid on common shares, return on assets, average annual assets and return on equity. The value of the determination coefficient is 0.408 , that means that the variation of the resultant variable is attributable for $40.8 \%$ to the variation of the explanatory variables of the model. 
The hypothesis about the statistical significance of the regression equation was tested by comparing the actual and critical (tabular) values of the F-Fisher' criterion. This model is statistically significant at a significance level of $95 \%$, since the following inequality is applied: $(\mathrm{F}$ critical $=2.394)<(\mathrm{F}$ observed $=66.757)$.

The results of observing the significance of the regression coefficients are shown in Table 6.

Table 6. Estimation of regression equation parameters

\begin{tabular}{|c|c|c|c|c|c|c|}
\hline & Coefficients & Standard error & $\begin{array}{c}\text { t-statistic } \\
\mathrm{s}\end{array}$ & P-value & $\begin{array}{c}\text { Lower } \\
95 \%\end{array}$ & $\begin{array}{c}\text { Upper } \\
95 \%\end{array}$ \\
\hline Y-intersection & 8,508 & 5,134 & 1,658 & 0,00 & $-1,583$ & 18,598 \\
\hline Return on assets & 19,701 & 3,043 & 6,475 & 0,00 & 13,719 & 25,683 \\
\hline $\begin{array}{c}\text { Annual average value } \\
\text { asset }\end{array}$ & 0,181 & 0,303 & 4,596 & 0,00 & $-0,416$ & 0,777 \\
\hline Return on equity & 1,241 & 0,219 & 5,651 & 0,00 & 0,809 & 1,673 \\
\hline
\end{tabular}

Further, using the t-test, the significance of the correlation coefficients obtained earlier was assessed. For this model, a tabular value was determined as following: $t$ crit. 2.249 (400 observations, 3 factors). The results of testing the factors included in the regression model on significance using the t-criterion are presented in Table 7.

Table 7. Comparison of the observed values of the t-test with the critical values of t-statistics

\begin{tabular}{ccc}
\hline Explanatory variable (regressor) & $\mathrm{t}_{\text {observed }}$ & $\mathrm{t}_{\text {critical }}$ \\
\hline Net profit & 3,658 & 2,249 \\
\hline Return on assets & 6,475 & 2,249 \\
\hline Annual average value asset & 4,596 & 2,249 \\
\hline Return on equity & 5,652 & 2,249 \\
\hline
\end{tabular}

Since all the observed values of the t-statistics in absolute value exceed the critical value, it is concluded that all factors of this regression model are recognized as significant.

Further, the Goldfeld-Quandt test for heteroscedasticity was applied. Since for each of the factors the inequality was fulfilled: $\mathrm{F}$ the highest. < F critical. Hence the residues are homoscedastic and the sample is homogeneous at the $95 \%$ probability level.

Therefore, there is a statistical confirmation for hypothesis about the existence of the connection between the dividend policy and the financial and investment policies of the company.

\section{Results and Discussion}

Based on the results of testing the first two hypotheses, it is concluded that such analyzed factors as revenue, the presence of the state and foreign investors in the ownership structure, are statistically insignificant.

The value of the elasticity coefficient reflects the degree of influence of the factor on the amount of dividend payments. The results of ranking the significant factors of the linear regression model by the value of the elasticity coefficient are demonstrated in Table 8.

Table 8. Elasticity coefficients of significant regressors by the amount of dividend payments

\begin{tabular}{ccc}
\hline Explanatory variable (regressor) & Value of the elasticity coefficient & Factor rank \\
\hline Belonging to the oil and gas sector & 1,820 & 1 \\
\hline Capitalization & 1,679 & 2 \\
\hline Net profit & 0,283 & 3 \\
\hline
\end{tabular}


According to Table 8, dividend payments made by domestic public companies have a positive impact on capitalization. This result is quite expected, as net profit is the main source of dividend payments.

The significant positive connection between the factor of belonging to the oil and gas sector and the size of dividend payments is explained by the fact that companies in this sector possess assets that are significantly larger than those of the other sectors; and, therefore, generate the highest values of revenues and net profit.

The results of testing the third and fourth hypotheses regarding the connection between the dividend policy and the financial and investment policy demonstrated statistical insignificance in case of the financial leverage ratio, interest coverage ratio, and return on invested capital. Among the statistically significant factors in terms of the elasticity coefficient, the highest rank was obtained by the return on assets factor with the elasticity coefficient equal to 19.7. As far as the return on assets indicator characterizes the return on invested capital, it also demonstrates the effectiveness of the company's investment policy, what also meets the expected results.

The return on equity indicator has the second rank (the value of the elasticity coefficient is 1.241), and demonstrates a positive connection with the amount of dividend payments.

The factor of the average annual value of assets has the lowest rank with a value of the elasticity coefficient equal to 0.181 , and also shows a positive connection with the resulting factor - that is in line with expectations as well. The reason of this is that the given indicator characterizes the size of the company - the larger the company, the more revenue and, hence, the larger net profit it generates. This ultimately has a positive effect on the value of dividend payments.

\section{Summary}

While researching on the features of the dividend policy of Russian public companies in the period from 2011 to 2018 and referring to the results of the empirical research, statistical data, and analytical reviews, the following important characteristics and trends are pointed out (https://www.finam.ru; Национальное рейтинговое агентство, 2019):

- Increased frequency of dividend payments made by large corporations;

- Closed nature of many domestic companies in terms of information, and the formation of dividend payments based on the residual principle;

- Development of a new form of dividend payment on the Russian market - share buy-back;

- The presence of a significant share of the state, local authorities, insiders and majority shareholders;

- Serious sectoral imbalances in the sectors of the national economy;

- The ambiguous consequences of the economic sanctions imposed by various countries against the Russian Federation, starting from 2014;

- Growth in the total dividend yields of Russian stock exchange indices;

- The growing role of the dividend component in the formation of the total return on shares of Russian companies.

\section{Conclusion}

Ensuring the growth of the company's market capitalization and finding the optimal balance of two different types of profit - the one distributed among the owners and the other which is capitalized, is an important task of the management of domestic public companies in the course of the formation and implementation of the dividend policy at the modern stage.

An empirical study of 50 large domestic companies in the period from 2011 to 2018 showed a significant connection between the number of dividends paid on common shares and the company's net income, market capitalization, belonging to the oil and gas sector, return on assets, average annual value assets, and return on equity.

The use of multivariate regression models in the course of substantiating decisions on the payment of dividends would allow the management of companies to evaluate, predict and consider in practice the intricacies of decisions on the payment of dividends and financial and investment decisions. At the same time, the main objective of management is to find a reasonable compromise between a stable increase in market capitalization and meeting shareholders' expectations.

\section{Acknowledgements}

The work is performed according to the Russian Government Program of Competitive Growth of Kazan Federal University. 


\section{References}

Baker, H. K., \&. Powell, G. E. (1999). How Corporate Managers View Dividend Policy. Quarterly Journal of Business and Economics, 38, 17-35.

Dhanani, A. (2005). Corporate Dividend Policy: The Views of British Financial Managers. Journal of Business Finance and Accounting, 32, 1625-1672.

Fama, E. F., \& Babiak, E. F. (1968). Dividend Policy: an Empirical Analysis. Journal of the American Statistical Association, 63, 1132-1161.

Fama, E. F., \& French. (2001). Disappearing Dividends: Changing Firm Charachteristics or Lower Propensity to Pay?. Journal of Financial Economics, 3-43.

Kozlova, A. S. (2015). Factors influencing the formation of the dividend policy of Russian companies. Bulletin of the Saratov State Socio-Economic University, 4(58), 54-57.

Levanova, L. N. (2019). Development of the dividend policy in Russian corporations. Actual problems of social and humanitarian sciences and education: essence, concepts, prospects, 1028-1033.

Litner, J. (1956). Distribution of Incomes of Corporations among Dividends, Retained Earnings, and Taxes. American Economic Review, 46, 97-113.

National Rating Agency. (2019). Analytical review "Dividend payments of Russian companies for 2013-2018" National Rating Agency. National Rating Agency, 3-25.

Russian stocks-quotes, rates, cost [Electronic resource]. JSC " Investment Company "FINAM". Retrieved January 6, 2020, from https://www.finam.ru/quotes/stocks/russia

SPARK-Interfax-Verification of the counterparty [Electronic resource]. JSC "Interfax News Agency". Retrieved January 6, 2020, from https://spark-interfax.ru/

Teplova, T. V., \& Saltzman, A. A. (2015). Cross-country comparative analysis of the practice of dividend payments: Russian and foreign experience. Russian Journal of Management, 13(2), 29-66.

\section{Copyrights}

Copyright for this article is retained by the author(s), with first publication rights granted to the journal.

This is an open-access article distributed under the terms and conditions of the Creative Commons Attribution license (http://creativecommons.org/licenses/by/4.0/). 